\title{
Preparation and Properties of Polyester-Based Nanocomposite Gel Coat System
}

\author{
P. Jawahar and M. Balasubramanian \\ Composites Technology Center and Department of Metallurgical and Materials Engineering, Indian Institute of Technology, \\ Madras, Chennai 600036, India
}

Received 30 January 2006; Revised 19 July 2006; Accepted 13 December 2006

\begin{abstract}
Nanocomposite gel coat system is prepared using unsaturated polyester resin with aerosil powder, $\mathrm{CaCO}_{3}$, and organoclay. The influence of organoclay addition on mechanical and water barrier properties of gel coat system is studied for different amount (1, 2 , and $3 \mathrm{wt} \%$ ) of organoclay. The nanolevel incorporation of organoclay improves the mechanical and water barrier properties of nanocomposite gel coat system. The nanocomposite gel coat system exhibits 55\% improvement in tensile modulus and $25 \%$ improvement in flexural modulus. There is a 30\% improvement in impact property of nanocomposite gel coat system. The dynamic mechanical analysis shows a slight increase in glass transition temperature for nanocomposite gel coat system.
\end{abstract}

Copyright (c) 2006 P. Jawahar and M. Balasubramanian. This is an open access article distributed under the Creative Commons Attribution License, which permits unrestricted use, distribution, and reproduction in any medium, provided the original work is properly cited.

\section{INTRODUCTION}

At present, the research attention has been focused on a new class of material called "clay polymer nanocomposites" after the discovery that polymer properties can be significantly improved by the presence of nanosize clay particles [1-3]. Lots of research works have been carried out in different polymer systems [4-8] based on this concept. Smectite group clays are normally used as a basic reinforcing element in nanocomposites, because of the high aspect ratio and platy morphology [9-11].

The montmorillonite clay belongs to the family of Smectite clays. It is a crystalline material consisting of $1 \mathrm{~nm}$ thick sheets. These silicate sheets consist of alumina octahedra sandwiched by two silica tetrahedra. The length of the individual sheets can range from 30 to $100 \mathrm{~nm}$. Isomorphic substitution of alumina by magnesium results in net negative charge on the surface of the sheets which is balanced by exchangeable cations like $\mathrm{Na}^{+}$or $\mathrm{Ca}^{+}$. These cations can be readily exchanged with alkyl-ammonium ions on organomodification. These alkyl-ammonium ions lowers the surface energy of the inorganic host and improve the wetting characteristics with the polymer [12].

Incorporation of nanosize clay platelets to the polymer matrix increases modulus and strength [13]. Nanosize clay platelets decrease permeability $[14,15]$, shrinkage $[16,17]$, and increase resistance to heat and flammability
$[18,19]$. The fracture energy of the clay-polyester nanocomposite could be doubled even at low concentration (1.5 wt \%) of clay [20]. The formation mechanism based on fabrication methods has been reported for unsaturated polyesterlayered silicate nanocomposites [21]. The method of mixing clay in polyester resin, curing agents, and curing conditions influence the properties of nanocomposites [22, 23]. The effect of nanoclay on the cure kinetics of unsaturated polyester resin in the range of 35 to $65^{\circ} \mathrm{C}$ was investigated by $\mathrm{Xu}$ and Lee [24]. The clay-polyester nanocomposites produced using reactive organoclay had better dynamic modulus [25].

Composites with gel coats are an essential part of many aspects of life today; from bathroom units to boats; from cultured marble to airplane structures; from windmills to automotive parts. Gel coat imparts good surface finish and bears better hardness, scratch resistance, and resistance to corrosion and water absorption to the composites. It is expected that the incorporation of nanoclay in gel coat would lead to an improvement in the properties, which will make the material viable in high-loading environment.

In the present work, nanocomposite gel coat system was prepared using unsaturated polyester resin with aerosil and $\mathrm{CaCO}_{3}$ powders and organoclay. The influence of organoclay addition on mechanical, thermal, and water barrier properties of gel coat system has been studied. 


\section{EXPERIMENTAL PROCEDURE}

The resin used for gel coat is isophthalic polyester resin (PE), procured from Vasavibala resins (P) Ltd., Chennai. The organo-modified clay (OMC) used is dodecylamine treated montmorillonite clay processed in the laboratory as reported elsewhere [26]. Fillers used are $\mathrm{CaCO}_{3}$ powders of average size $48 \mu \mathrm{m}$ and aerosil powder of average size $6 \mu \mathrm{m}$ procured from Jain Industrial chemicals, Chennai.

$300 \mathrm{ml}$ of isophthalic polyester resin was taken in a container. Organoclay of definite proportion $(1,2$, and $3 \mathrm{wt} \%)$ was added to produce nanoclay dispersed polyester mix. It was stirred well using a mechanical stirrer at $1000 \mathrm{rpm}$ for $1 \mathrm{~h}$. To produce nanocomposite gel coat system, $2 \mathrm{wt} \%$ of aerosil powder was added to the clay dispersed resin and mixed manually using glass rod and then $10 \mathrm{wt} \%$ of calcium carbonate was added and mixed well. Similarly, conventional gel coat system was also prepared with the same procedure without the addition of nanoclay to the polyester resin. Methyl ethyl ketone peroxide catalyst (1.5 wt \%) and cobalt napthanate accelerator $(1.5 \mathrm{wt} \%)$ were added to the mixture to initiate the curing reaction. Sheets of size $300 \times$ $300 \times 3 \mathrm{~mm}^{3}$ were cast in a glass mold and allowed to cure for $24 \mathrm{~h}$ at room temperature followed by post curing at $70^{\circ} \mathrm{C}$ for $3 \mathrm{~h}$.

$\mathrm{X}$-ray diffraction (XRD) was carried out for organoclayfilled polyester to study the state of clay dispersion. It was carried out with a scanning rate of $2^{\circ} / \mathrm{min}$ with $\mathrm{Cu}-\mathrm{K} \alpha$ radiation using SHIMADZU, XD-DI X-ray diffractometer. Transmission electron microscopic characterization was carried out using JEOL JEM 1200EX electron microscope. The density of gel coat systems was measured using Archimedes principle.

Tensile tests (ASTM D-638) were performed at room temperature using Instron 4301 universal testing machine (UTM), with a crosshead speed of $2 \mathrm{~mm} / \mathrm{min}$. Mechanically fractured tensile samples were analyzed using JEOL JSM-840 A scanning electron microscope (SEM) with EDAX. Flexural properties were evaluated using Instron 4301 UTM as per ASTM D-790 standard. Izod impact strength was determined using Frank impact testing machine following ASTM D-256 standard. A 7.5 joules izod impact hammer was used. Dynamic mechanical analysis (DMA) was performed using Netzsch (DMA 242C) dynamic-mechanical analyzer in the three-point bending mode at a frequency of $10 \mathrm{~Hz}$ and amplitude of $120 \mu \mathrm{m}$ over the temperature range of $30-180^{\circ} \mathrm{C}$ at the heating rate of $5^{\circ} \mathrm{C} / \mathrm{min}$. Water barrier properties were determined according to ASTM D-570.

\section{RESULTS AND DISCUSSION}

XRD patterns of organoclay (OMC) and polyester filled with OMC are shown in Figure 1. The 001 basal plane diffraction peak of OMC is absent in composites filled with organoclay $(1,2$, and $3 \mathrm{wt} \%)$. This reveals that the interlayer distance of OMC is more than $70 \AA$ or the layers are randomly dispersed in the polymer matrix.

Figure 2 shows the TEM micrograph of polyester filled with 1,2 , and $3 \mathrm{wt} \%$ organoclay. The clay platelets are well

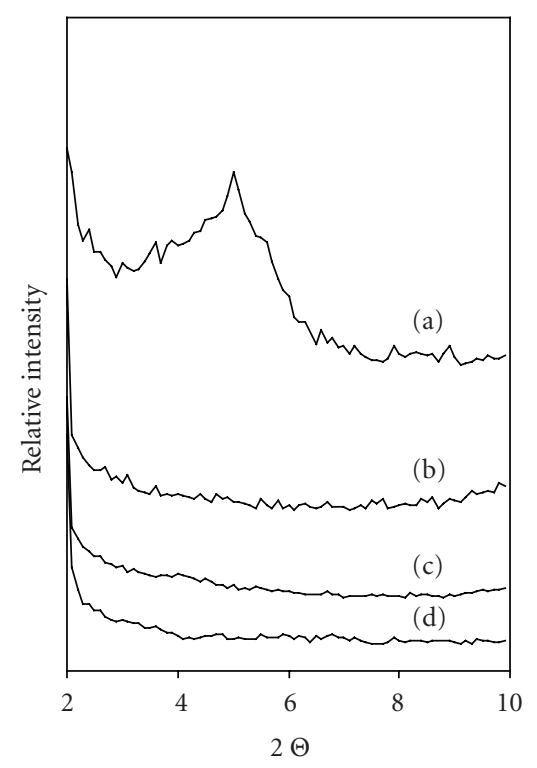

FIGURE 1: XRD patterns for (a) organoclay and polyester with (b) 1 wt \% OMC, (c) 2 wt \% OMC, (d) 3 wt \% OMC.

exfoliated and spacing between the clay platelets is more than $70 \AA$ A. This confirms the formation of well-exfoliated structure on addition of 1,2 , and $3 \mathrm{wt} \%$ organoclay and also supports the XRD data.

Density values of conventional gel coat and nanocomposite gel coat are shown in Figure 3. The density of conventional gel coat system is $1.41 \mathrm{~g} / \mathrm{cm}^{3}$. It remains almost same with the addition of organoclay up to $2 \mathrm{wt} \%$. The density decreases to $1.32 \mathrm{~g} / \mathrm{cm}^{3}$ for the organoclay content of $3 \mathrm{wt} \%$. The decrease in density of nanocomposite gel coat with $3 \mathrm{wt} \%$ may be due to the presence of pores. During mixing of organoclay with polyester resin, the viscosity increases and it is high for the organoclay content of $3 \mathrm{wt} \%$. So the entrapped air during mixing finds it difficult to escape out of polyester matrix and remains as pores.

The tensile properties of gel coat system with and without clay are shown in Figures 4 and 5. The tensile strength of conventional gel coat is $38 \mathrm{MPa}$ (Figure 4). Tensile strength increases with increase in organoclay content. It increases to the value of $46 \mathrm{MPa}$ for the organoclay content of $2 \mathrm{wt} \%$. Thereafter, it decreases to the value of $33 \mathrm{MPa}$. The tensile modulus follows an increasing trend (Figure 5). It increases from the value of $4.5 \mathrm{GPa}$ for conventional gel coat to the value of $7 \mathrm{GPa}$ for the organoclay content of $3 \mathrm{wt} \%$.

Figure 6 shows the fracture surface of conventional gel coat system and nanocomposite gel coat systems with 1 , 2 , and $3 \mathrm{wt} \%$ organoclay. The mode of failure is brittle in both the gel coats. The facets on fracture surface of conventional gel coat appear glassy. It indicates that the material is highly brittle and the mode of failure is highly catastrophic. In the case of nanoclay dispersed gel coat system, the fracture surface seems to be rough with fine facets. This indicates the formation of strong bonding between nanoclay and polyester resin and due to this, the nanocomposite gel coat 


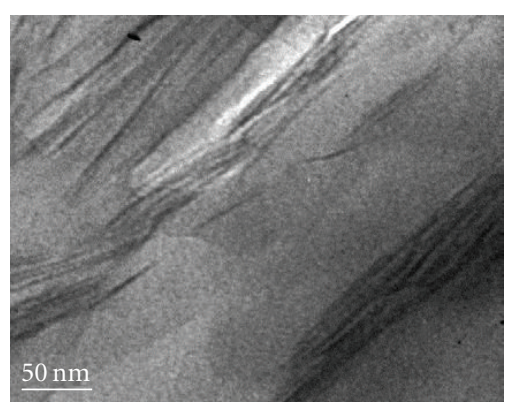

(a)

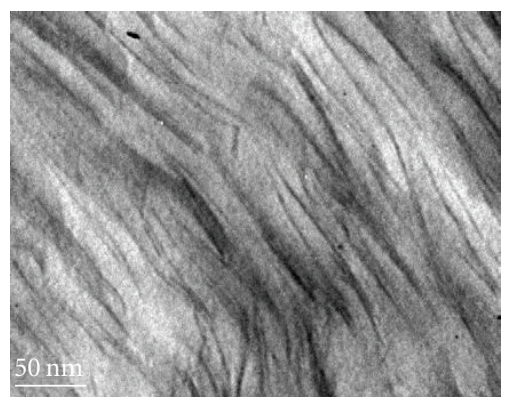

(b)

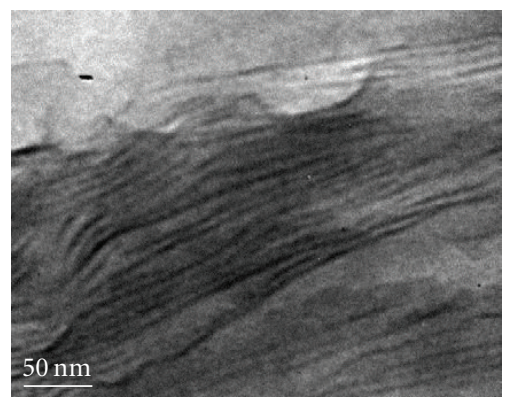

(c)

FIgURE 2: TEM micrographs of polyester filled with (a) $1 \mathrm{wt} \%$ OMC, (b) 2 wt \% OMC, and (c) 3 wt \% OMC.

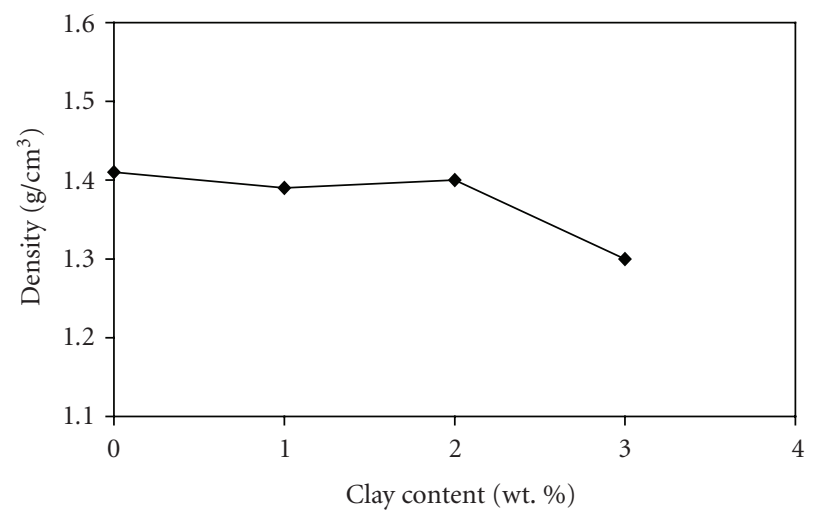

FIGURE 3: Density of gel coat systems.

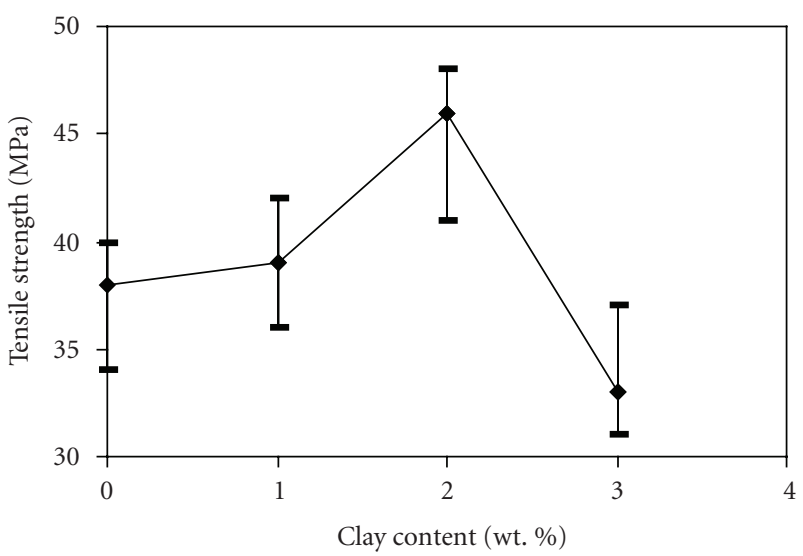

Figure 4: Tensile strength of gel coat systems.

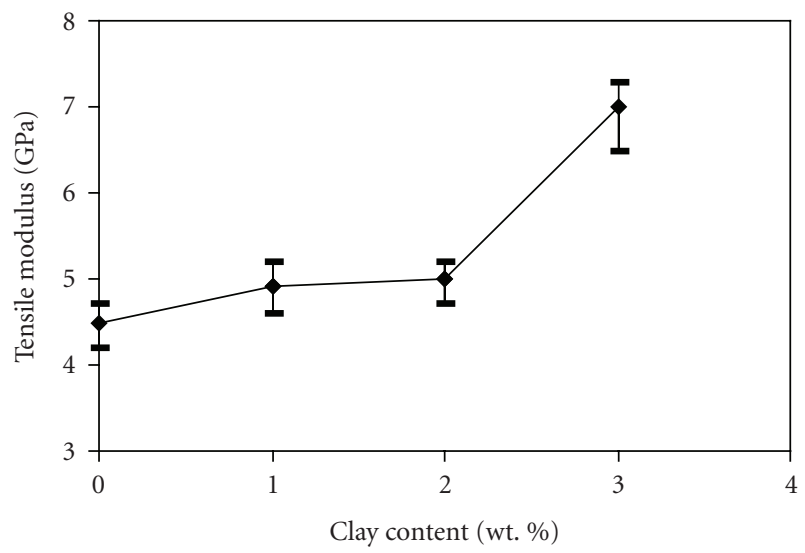

Figure 5: Tensile modulus of gel coat systems.

system with 1 and 2 wt \% organoclay has better strength. For nanocomposite gel coats with $3 \mathrm{wt} \%$ organoclay, the facets are large compared to the gel coat system with 1 and $2 \mathrm{wt} \%$ organoclay. This indicates that the nanocomposite gel coat with 3 wt \% organoclay has less load bearing capacity. The tensile fracture surface of conventional gel coat shows agglomerates of $\mathrm{CaCO}_{3}$ and aerosil powder. EDAX analysis (Figure 7) of agglomerates shows more calcium content (Figure $7(\mathrm{a})$ ). The amount of calcium found in the agglomerates region is $25.24 \mathrm{wt} \%$, whereas the analysis carried out on the entire region shows a nominal value of $9.05 \mathrm{wt} \% \mathrm{Ca}$ (Figure 7(b)). EDAX analysis confirms the presence of agglomerated $\mathrm{CaCO}_{3}$ fillers in the conventional gel coat system. Surprisingly no agglomerates are found for nanocomposite gel coat system. This suggests that the exfoliated clay platelets present in the polyester matrix might be inducing some mechanism to prevent agglomeration of fillers.

Flexural strength of conventional gel coat system is $95 \mathrm{MPa}$ (Figure 8). It increases to the value of $105 \mathrm{MPa}$ for the nanocomposite gel coat system with $2 \mathrm{wt} \%$. Thereafter, it decreases to the value of $91 \mathrm{MPa}$ for the clay content of $3 \mathrm{wt} \%$. The flexural modulus increases from the value of $3.9 \mathrm{GPa}$ for 


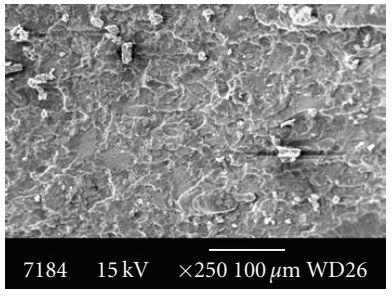

(a)
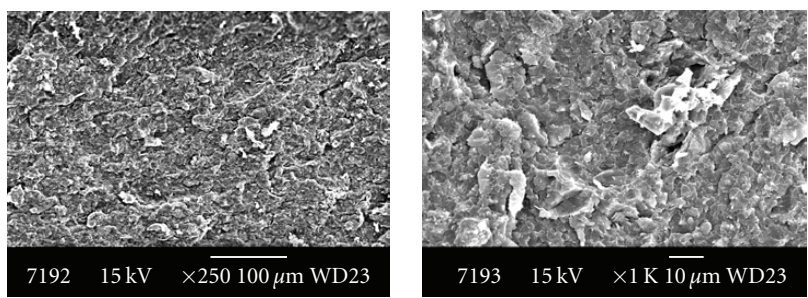

(c)

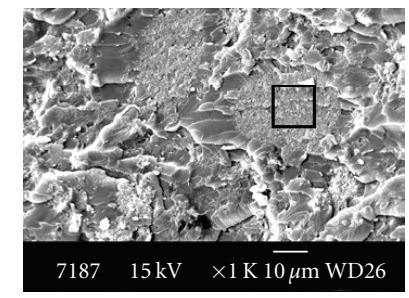

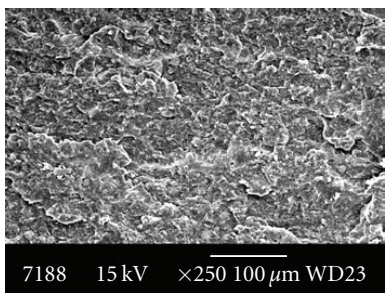

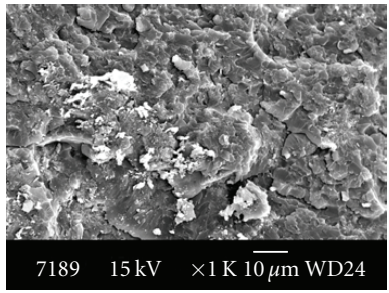

(b)
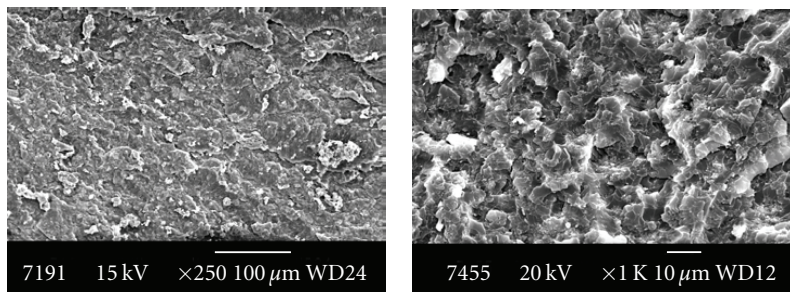

(d)

FIGURE 6: SEM micrographs of tensile fracture surface for (a) conventional gel coat and nanocomposite gel coats with (b) 1 wt \% OMC, (c) 2 wt \% OMC, (d) 3 wt \% OMC.

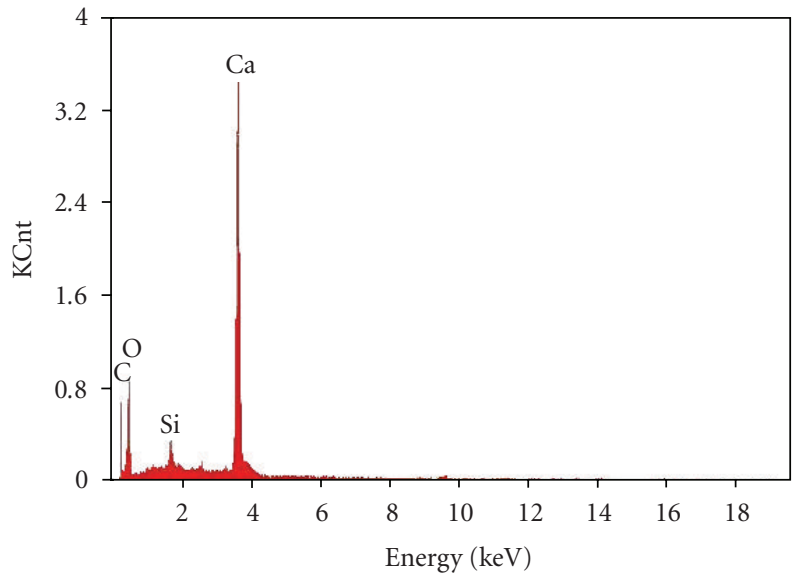

(a)

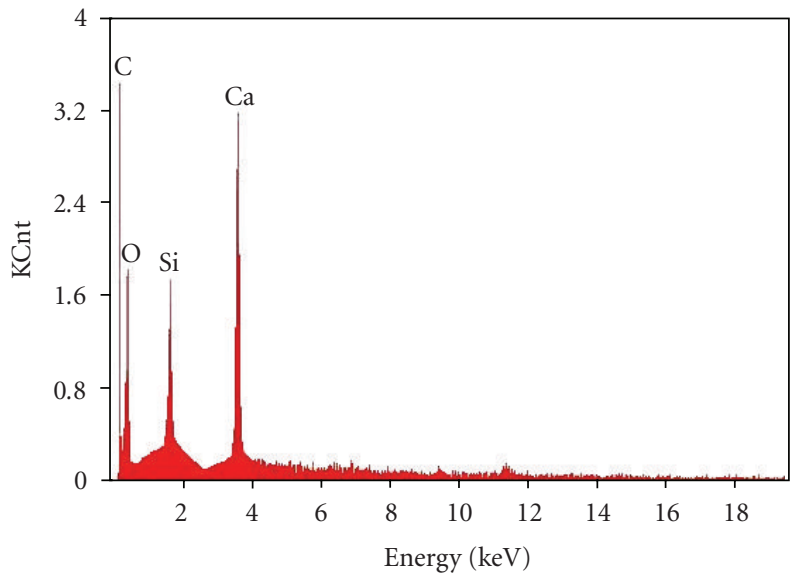

\begin{tabular}{lll}
\hline Element & $w t \%$ & at $\%$ \\
\hline $\mathrm{CK}$ & 49.25 & 57.91 \\
$\mathrm{OK}$ & 40.06 & 36.86 \\
$\mathrm{SiK}$ & 01.64 & 01.91 \\
$\mathrm{CaK}$ & 09.05 & 03.32 \\
\hline
\end{tabular}

(b)

\begin{tabular}{lll}
\hline Element & $w t \%$ & $a t \%$ \\
\hline $\mathrm{CK}$ & 25.71 & 37.00 \\
$\mathrm{OK}$ & 47.13 & 50.93 \\
$\mathrm{SiK}$ & 01.92 & 01.18 \\
$\mathrm{CaK}$ & 25.24 & 10.89 \\
\hline
\end{tabular}

\begin{tabular}{ll}
09.05 & 03.32 \\
\hline
\end{tabular}

FIGURE 7: EDAX on conventional gel coat (a) agglomerated region (marked in Figure 6(a)), (b) entire region. 


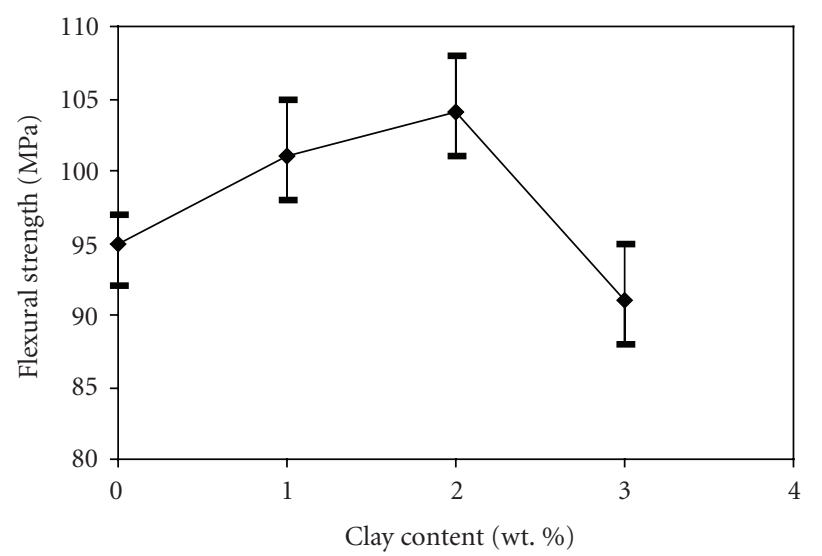

Figure 8: Flexural strength of gel coat systems.

conventional gel coat system to the value of $5.2 \mathrm{GPa}$ for the nanocomposite gel coat system with a clay content of $3 \mathrm{wt} \%$ (Figure 9).

The improvement in mechanical properties is due to the presence of well-exfoliated nanoclay and interaction of nanosize clay layers with the polymer matrix, as well as on the rigid nature of the clay layers [27]. Crack pinning and crack bifurcation are some of the strengthening mechanisms responsible for the increase in strength of nanocomposites $[20,28,29]$.

Improvement in tensile strength and flexural strength is not significant for nanocomposite gel coat system with $3 \mathrm{wt} \%$ organoclay. Even though the nanosize clay acts as load bearing component, the dispersion of exfoliated clay platelets might have hindered the crosslinking of the polymer chains [30]. The decrease in strength at higher clay content (3 wt \%) may also be due to the increase in viscosity of the polyester resin. The increase in viscosity may lead to improper mixing of $\mathrm{CaCO}_{3}$ and aerosil powders. Moreover, the air entrapped during shear mixing may not escape out of the system and remains as micropore in the nanocomposite gel coats, which leads to a decrease in strength.

Impact strength of the conventional gel coat system is $85 \mathrm{~J} / \mathrm{m}$ (Figure 10). It increases to $106 \mathrm{~J} / \mathrm{m}$ and $113 \mathrm{~J} / \mathrm{m}$ for the organoclay contents of 1 and $2 \mathrm{wt} \%$, respectively. It decreases to the value of $96 \mathrm{~J} / \mathrm{m}$ for the organoclay content of $3 \mathrm{wt} \%$. The nanosize clay platelets play a vital role for the improvement in impact strength. The nanoclay acts as crack stoppers with increase in organoclay content and form a tortuous pathway for crack propagation resulting in higher impact energy [31].

Storage modulus is higher for the gel coat system with organoclay (Figure 11). At $40^{\circ} \mathrm{C}$ the conventional gel coat system has a storage modulus of $7432 \mathrm{MPa}$. The storage modulus for nanocomposite gel coat systems are $7794 \mathrm{MPa}$, $8435 \mathrm{MPa}$, and $7557 \mathrm{MPa}$ for the organoclay content of 1, 2, and $3 \mathrm{wt} \%$, respectively. The improvement in storage modulus is due to the presence of exfoliated clay platelets in the polyester matrix. The deterioration in properties for $3 \mathrm{wt} \%$

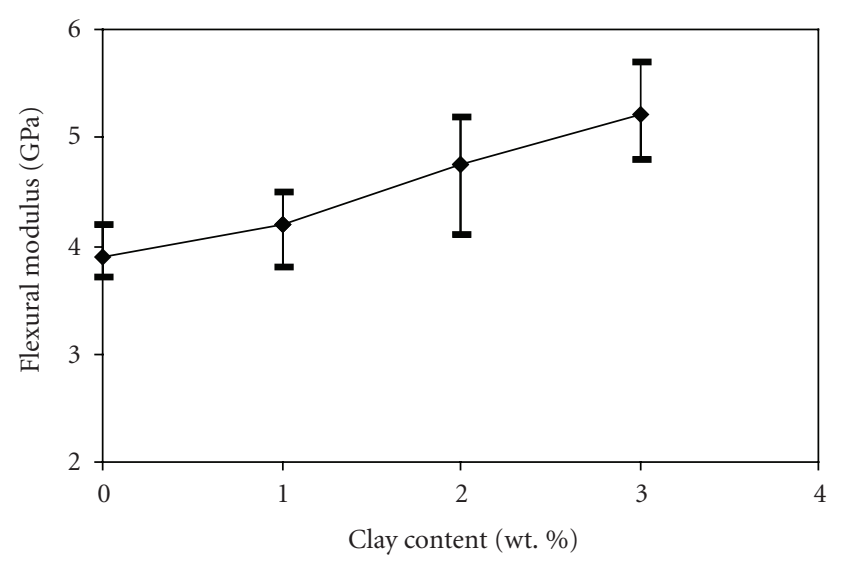

FIGURE 9: Flexural modulus of gel coat systems.

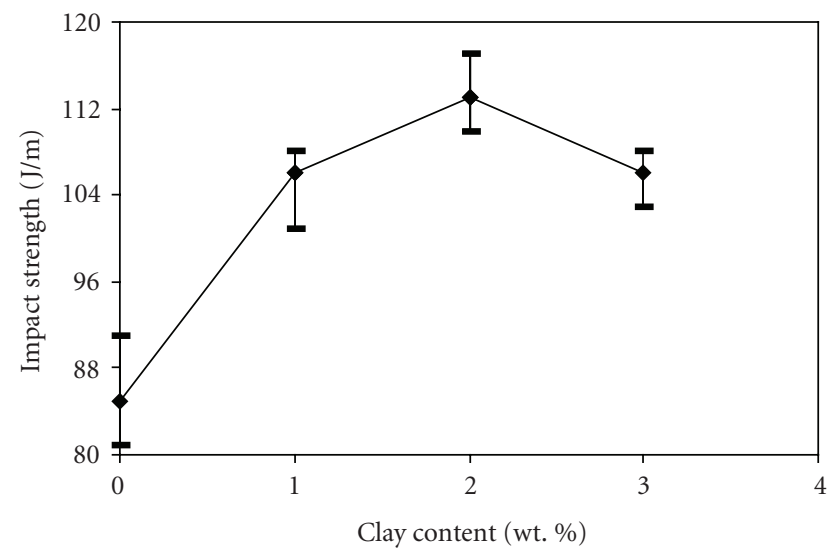

Figure 10: Impact strength of gel coat systems.

organoclay may be due to the presence of pores, which is confirmed by the decrease in density (Figure 3 ).

Figure 12 shows the variation of damping factor $(\tan \delta)$ for conventional and nanocomposite gel coat systems. The damping factor increases on addition of organoclay. The stiffness variation between the nanoclay and polymer matrix might have caused internal damping, resulting in increased damping factor for nanocomposite gel coats [32].

Glass transition temperature $\left(\mathrm{T}_{g}\right)$ corresponds to the peak $\tan \delta$ value in the dynamic mechanical analysis curve (Figure 12). $\mathrm{T}_{g}$ increases slightly on addition of organoclay from the value of $117^{\circ} \mathrm{C}$ for conventional gel coat system to the value of $123^{\circ} \mathrm{C}$ for the nanocomposite gel coat system containing $1 \mathrm{wt} \%$ organoclay and it decreases to the value of $121^{\circ} \mathrm{C}$ for the nanocomposite gel coat system containing 3 wt $\%$ organoclay. The decrease in $\mathrm{T}_{g}$ for the nanocomposite gel coat system with $3 \mathrm{wt} \%$ clay indicates that there is reduction in crosslink density. This improvement in $\mathrm{T}_{g}$ suggests that the clay nanofillers stiffens the polymer matrix at high temperatures. Due to the large surface area of the nanoclay platelets, large amount of polymer chains have strong contact with the clay surfaces and prevents segmental motion of the polymeric chains [27]. At increased temperature, many 


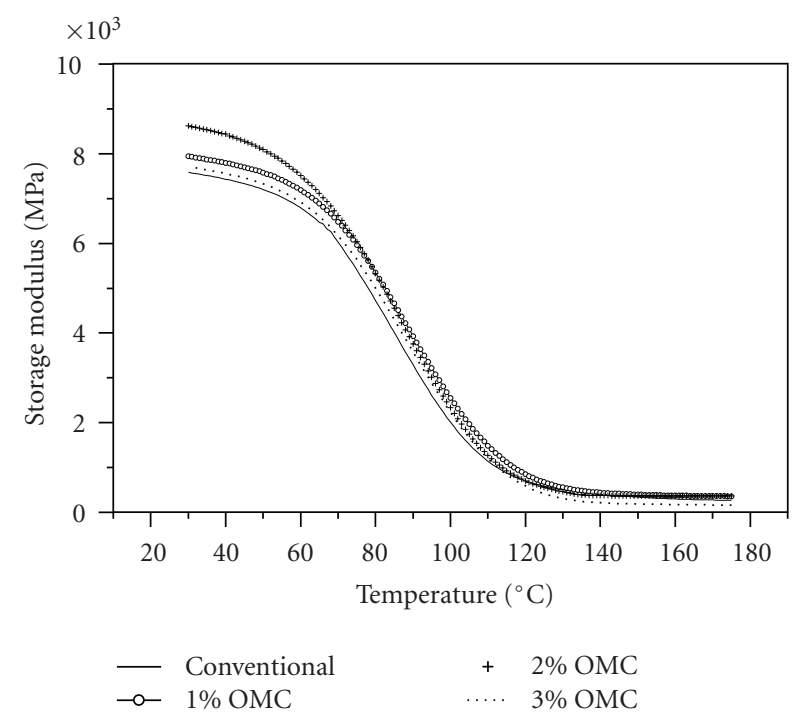

FIGURE 11: Storage modulus of gel coat systems.

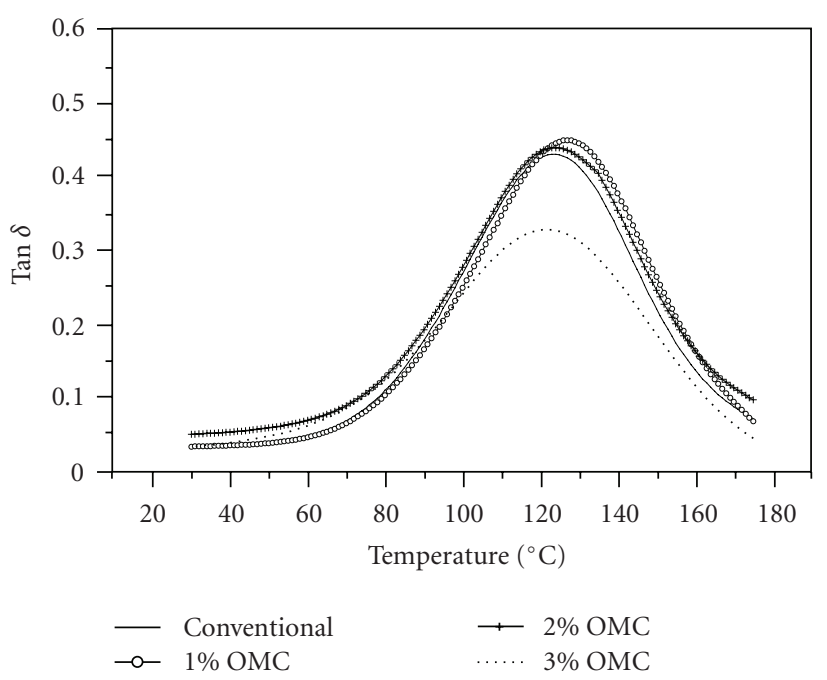

FIGURE 12: Loss factor $(\tan \delta)$ of gel coat systems.

polymeric chains will not experience softness due to the hard barrier phase.

Water absorption of conventional and nanocomposite gel coat systems are shown in Figure 13. The water absorption resistance for nanocomposite gel coat system is better compared to the conventional gel coat. Water absorption resistance increases with the addition of organoclay up to $2 \mathrm{wt} \%$. It decreases on further clay addition, but it is well above the limit compared to the conventional gel coat. The exfoliated clay platelets present in the polyester matrix act as barrier and increases the mean effective path for the water molecules to travel, and also lead to an increase in water absorption resistance [33].

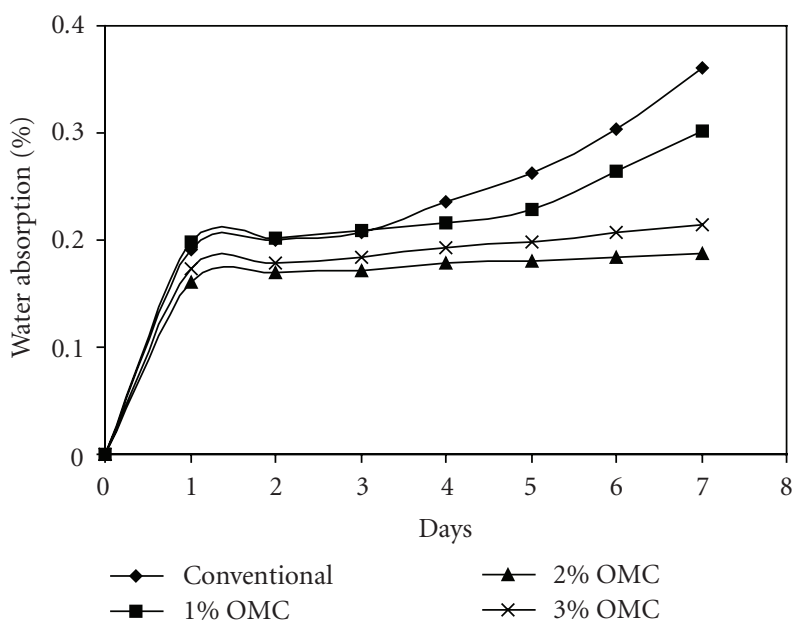

FIgURE 13: Water absorption of gel coat systems.

\section{CONCLUSIONS}

Nanocomposite gel coat systems were prepared using unsaturated polyester resin as matrix with aerosil and $\mathrm{CaCO}_{3}$ powders and organoclay. The nanolevel incorporation of organoclay improves the mechanical and water barrier properties of nanocomposite gel coat systems. The dynamic mechanical analysis shows a slight improvement in storage modulus and glass transition temperature for nanocomposite gel coat systems.

\section{REFERENCES}

[1] A. Usuki, M. Kawasumi, Y. Kojima, A. Okada, T. Kurauchi, and O. Kamigaito, "Swelling behavior of montmorillonite cation exchanged for $\omega$-amino acids by $\epsilon$-caprolactam," Journal of Materials Research, vol. 8, no. 5, pp. 1174-1178, 1993.

[2] A. Usuki, Y. Kojima, M. Kawasumi, et al., "Synthesis of nylon 6-clay hybrid," Journal of Materials Research, vol. 8, no. 5, pp. 1179-1184, 1993.

[3] Y. Kojima, A. Usuki, M. Kawasumi, A. Okada, T. Kurauchi, and O. Kamigaito, "Synthesis of nylon 6-clay hybrid by montmorillonite intercalated with $\epsilon$-caprolactam," Journal of Polymer Science Part A: Polymer Chemistry, vol. 31, no. 4, pp. 983-986, 1993.

[4] X. Kornmann, H. Lindberg, and L. A. Berglund, "Synthesis of epoxy-clay nanocomposites: influence of the nature of the clay on structure," Polymer, vol. 42, no. 4, pp. 1303-1310, 2001.

[5] M. Krook, A.-C. Albertsson, U. W. Gedde, and M. S. Hedenqvist, "Barrier and mechanical properties of montmorillonite/polyesteramide nanocomposites," Polymer Engineering \& Science, vol. 42, no. 6, pp. 1238-1246, 2002.

[6] D. M. Delozier, R. A. Orwoll, J. F. Cahoon, J. S. Ladislaw, J. G. Smith Jr., and J. W. Connell, "Polyimide nanocomposites prepared from high-temperature, reduced charge organoclays," Polymer, vol. 44, no. 8, pp. 2231-2241, 2003.

[7] B. K. Kim, J. W. Seo, and H. M. Jeong, "Morphology and properties of waterborne polyurethane/clay nanocomposites," European Polymer Journal, vol. 39, no. 1, pp. 85-91, 2003. 
[8] A. Usoki, M. Kato, A. Okada, and T. Kurauchi, "Synthesis of polypropylene-clay hybrid," Journal of Applied Polymer Science, vol. 63, no. 1, pp. 137-139, 1997.

[9] P. D. Kaviratna, T. Lan, and T. J. Pinnavaia, "Synthesis of polyether-clay nanocomposites: kinetics of epoxide self-polymerization in acidic smectite clay," Polymer Preprints, vol. 35, no. 1, pp. 788-793, 1994.

[10] T. J. Pinnavaia, "Intercalated clay catalysts," Science, vol. 220, no. 4595 , pp. 365-371, 1983.

[11] T. Lan and T. J. Pinnavaia, "Clay-reinforced epoxy nanocomposites," Chemistry of Materials, vol. 6, no. 12, pp. 2216-2219, 1994.

[12] E. P. Giannelis, R. Krishnamoorti, and E. Manias, "Polymersilicate nanocomposites: model systems for confined polymers and polymer brushes," in Polymers in Confined Environments, vol. 138 of Advances in Polymer Science, pp. 107-147, Springer, New York, NY, USA, 1999.

[13] Y. Kojima, A. Usuki, M. Kawasumi, et al., "Mechanical properties of nylon 6-clay hybrid," Journal of Materials Research, vol. 8, no. 5, pp. 1185-1189, 1993.

[14] K. Yano, A. Usuki, A. Okada, T. Kurauchi, and O. Kamigaito, "Synthesis and properties of polymide-clay hybrid," Journal of Polymer Science Part A: Polymer Chemistry, vol. 31, no. 10, pp. 2493-2498, 1993.

[15] Y. Kojima, K. Fukumori, A. Usuki, A. Okada, and T. Kurauchi, "Gas permeabilities in rubber-clay hybrid," Journal of Materials Science Letters, vol. 12, no. 12, pp. 889-890, 1993.

[16] P. Kelly, A. Akelah, S. Qutubuddin, and A. Moet, "Reduction of residual stress in montmorillonite/epoxy compounds," Journal of Materials Science, vol. 29, no. 9, pp. 2274-2280, 1994.

[17] E. Haque and C. D. Armeniades, "Montmorillonite polymer concrete: zero-shrinkage and expanding polymer concrete with enhanced strength," Polymer Engineering \& Science, vol. 26, no. 21, pp. 1524-1530, 1986.

[18] E. P. Giannelis, "Polymer layered silicate nanocomposites," Advanced Materials, vol. 8, no. 1, pp. 29-35, 1996.

[19] J. D. Lee, T. Takekoshi, and E. P. Giannelis, "Fire retardant polyetherimide nanocomposites," in Proceedings of the Materials Research Society Symposium, vol. 457, pp. 513-518, Pittsburgh, Pa, USA, December 1997.

[20] X. Kornmann, L. A. Berglund, J. Sterte, and E. P. Giannelis, "Nanocomposites based on montmorillonite and unsaturated polyester," Polymer Engineering \& Science, vol. 38, no. 8, pp. 1351-1358, 1998.

[21] B. Lepoittevin, N. Pantoustier, M. Devalckenaere, et al., "Polymer/layered silicate nanocomposites by combined intercalative polymerization and melt intercalation: a masterbatch process," Polymer, vol. 44, no. 7, pp. 2033-2040, 2003.

[22] D. J. Suh, Y. J. Lim, and O. O. Park, "The property and formation mechanism of unsaturated polyester-layered silicate nanocomposite depending on the fabrication methods," Polymer, vol. 41, no. 24, pp. 8557-8563, 2000.

[23] I. Mironi-Harpaz, M. Narkis, and A. Siegmann, "Nanocomposite systems based on unsaturated polyester and organoclay," Polymer Engineering \& Science, vol. 45, no. 2, pp. 174186, 2005.

[24] L. Xu and L. J. Lee, "Kinetic analysis and mechanical properties of nanoclay reinforced unsaturated polyester (UP) resins cured at low temperatures," Polymer Engineering \& Science, vol. 45, no. 4, pp. 496-509, 2005.

[25] A. F. Xiao and Q. Syed, "Synthesis of unsaturated polyesterclay nanocomposites using reactive organoclays," Polymer Engineering \& Science, vol. 44, no. 2, pp. 345-351, 2004.
[26] R. Magaraphan, W. Lilayuthalert, A. Sirivat, and J. W. Schwank, "Preparation, structure, properties and thermal behavior of rigid-rod polyimide/montmorillonite nanocomposites," Composites Science and Technology, vol. 61, no. 9, pp. 12531264, 2001.

[27] J.-H. Chang, B.-S. Seo, and D.-H. Hwang, "An exfoliation of organoclay in thermotropic liquid crystalline polyester nanocomposites," Polymer, vol. 43, no. 10, pp. 2969-2974, 2002.

[28] W. Bernd, H. Frank, and Q. Z. Ming, "Epoxy nanocomposites with high mechanical and tribological performance," Composites Science and Technology, vol. 63, no. 14, pp. 2055-2067, 2003.

[29] J. H. Park and S. C. Jana, "The relationship between nano- and micro-structures and mechanical properties in PMMA-epoxynanoclay composites," Polymer, vol. 44, no. 7, pp. 2091-2100, 2003.

[30] R. K. Bharadwaj, A. R. Mehrabi, C. Hamilton, et al., "Structure-property relationships in cross-linked polyester-clay nanocomposites," Polymer, vol. 43, no. 13, pp. 3699-3705, 2002.

[31] A. B. Inceoglu and U. Yilmazer, "Synthesis and mechanical properties of unsaturated polyester based nanocomposites," Polymer Engineering \& Science, vol. 43, no. 3, pp. 661-669, 2003.

[32] C. T. Sun, S. K. Chaturvedi, and R. F. Gibson, "Internal damping of short-fiber reinforced polymer matrix composites," Computers \& Structures, vol. 20, no. 1-3, pp. 391-400, 1985.

[33] T. Lan, P. D. Kaviratna, and T. J. Pinnavaia, "On the nature of polyimide-clay hybrid composites," Chemistry of Materials, vol. 6 , no. 5, pp. 573-575, 1994. 

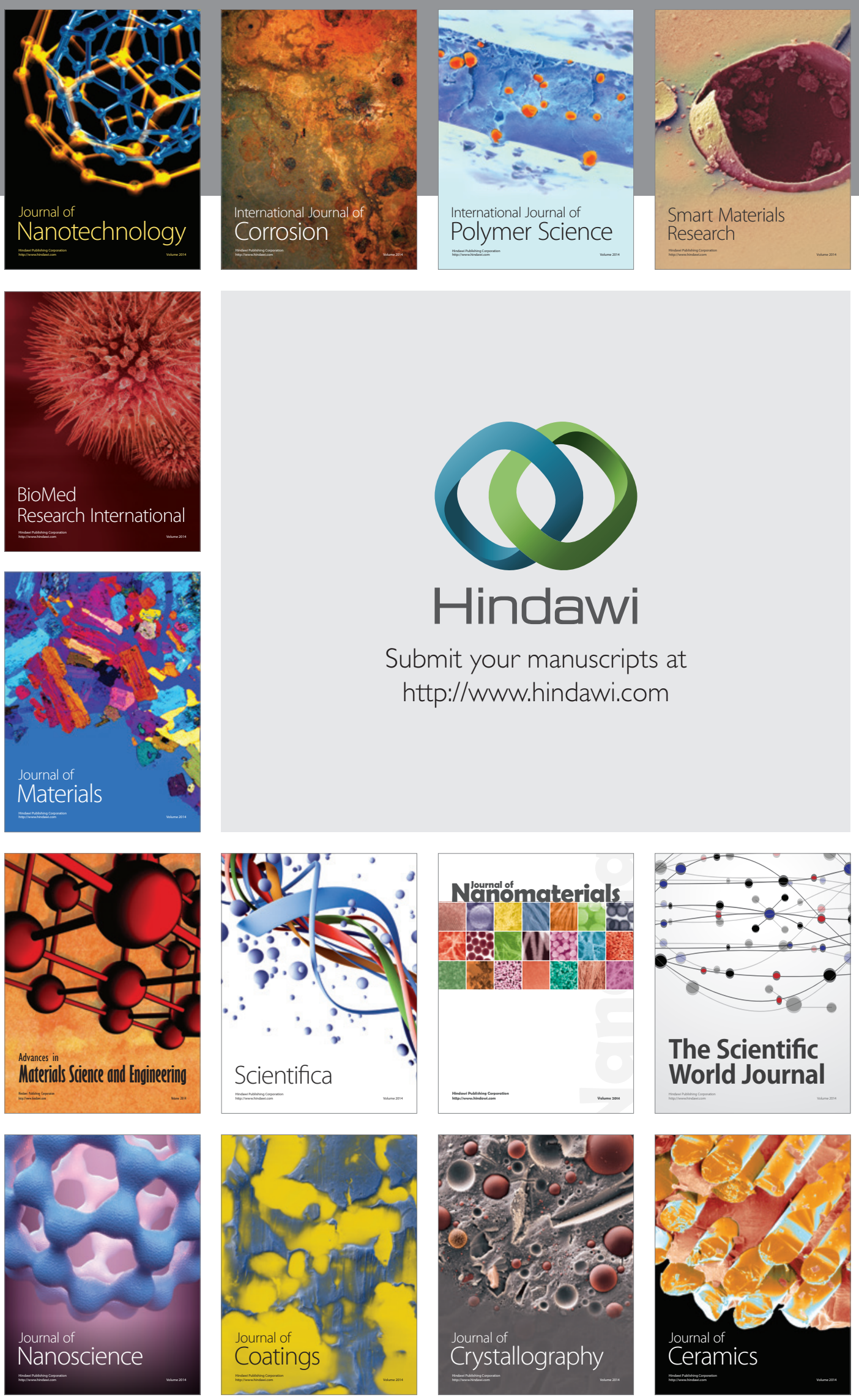

The Scientific World Journal

Submit your manuscripts at

http://www.hindawi.com

\section{World Journal}

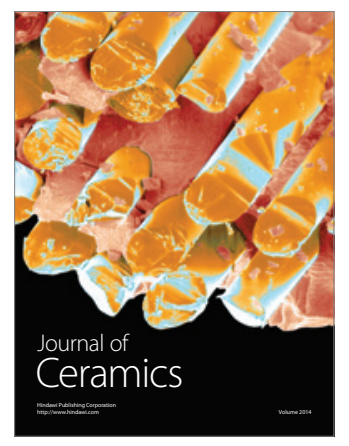

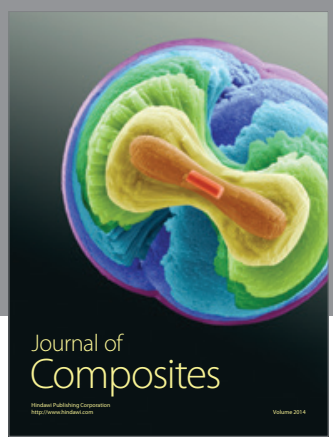
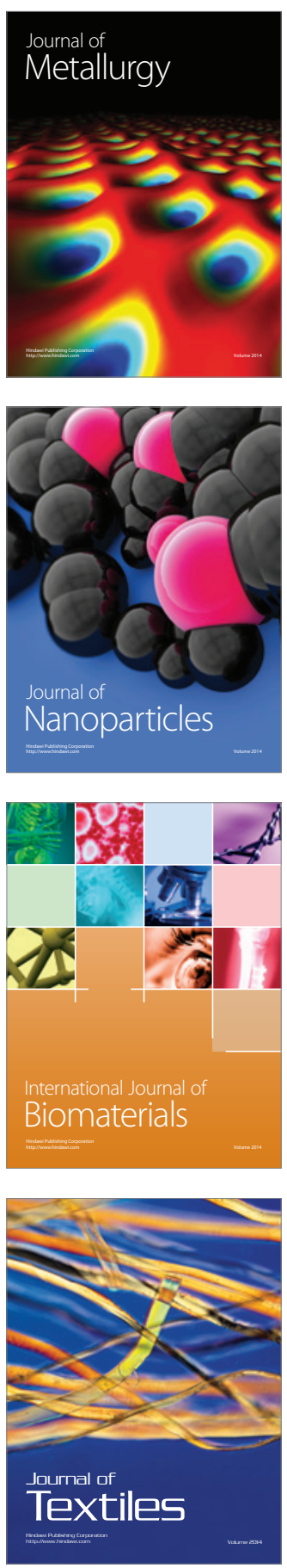